811.163.41'373.611

https://doi.org/10.18485/sj.2019.24.1.18

МИЛАН В. СТАКИТ *

Универзитет у Београду

Филолошки факултет
Оригинални научни рад

Примљен: 27. 11. 2018.

Прихваћен: 15. 01. 2019.

\title{
ИМЕНИЧКИ СУФИКС -СТВО У СРПСКОМ ЈЕЗИКУ
}

У раду ће се објашњавати продуктивни именички суфикс -ство: његово порекло, његово везивање за различите творбене основе и значења њиме изведених именица у савременом српском језику. Надаље, биће речи и о аломорфима и дериватима суфикса -ство. И све то на грађи прикупљеној из шестотомног Речника српскохрватскога књижевног језика Матице српске.

Кључне речи: суфикс -ство, аломорфи, деривати, изведенице, творбена структура, значења, деривациони однос, мотивне речи, придеви, именице.

Објаснити један суфикс значи говорити о више појединости: о пореклу тога суфикса, о значењу њиме изведених речи, о мотивним речима и њиховим творбеним основама, о деривационом односу мотивних и мотивисаних речи, о суфиксним аломорфима повезаним са гласовним алтернацијама на морфемном шаву творбене основе и суфикса, о суфиксним дериватима и њиховом начину и узроку јављања, о значењу помоћу њих изведених речи, о продуктивности датог суфикса и о његовим семантичким синонимима и, напослетку, о гласовним алтернацијама и фонемском уобличавању изведеница. Све ћемо ово покушати применити на именички суфикс -ство и на њиме изведене именице у савременом српском језику а на основу обимне грађе прикупљене из шестотомног Речника српскохрватскога киижевног језика Матице српске (надаље: РМС).

\footnotetext{
"mstakic@mts.rs
} 
Порекло. Било је више покушаја да се објасани порекло суфикса -ство. Навешћемо неке од њих, оне важније.

Петар Скок у трећем тому Етимологијског рјечника каже за суфикс -ство да је ,,sveslav. i prasl., živ i produktivan sufiks, bez paralela u baltičkoj grupi i ostalim ie. jezicima. Ide u grupu sufiksa koji služe za tvorenje apstrakta od imenica i pridjeva, izvedenih i neizvedenih ... Složen je od dva elementa, pridjevskog -bsk i od -tvo" (Скок 1973: 354). Осим мале непрецизности у обележавању придевског -bsk (место -bsk-), П. Скок је у праву и кад тврди да је то прасловенски суфикс, без паралела у балтичкој групи и у осталим индоевропским језицима и да је састављен од два елемента (придевског -bsk- и именичког -tvo).

A. Меје пише о суфиксима -tvo (-tva) и -stvo. Први доводи у везу са санскритским -tvám и каже да „в славянских языках уже не представлен”. Облик -stvo пореди с готским waurstw „,труд” и потврђује га примером „, БЂство 'бегство' в соответствии с въжати". Надаље, каже да је тај суфикс распрострањен „при помощи гласной -i-, позволяющей присоединять эту форму к основам, оканчивающимся на согласную, она дала продуктивный тип на -bstvo, часто распространенный вторичным суффиксом -ьје, а именно, -ьstv-ьје, дающее отвлеченные производные от имен; так, от отьць - отьчьство и отьчьствнк „родина”; от вогать - вогатьство и вогатьствні, и т. Д.” (Меје 1951: 296). - Овде би се могло прокоментарисати, и ставити под сумњу, неколико појединости: прво, облик -stvo потврђује само старословенско въство са значењем „бегство” и на страну то што један једини пример не значи много, овај облик ће, по нама, пре бити резултат морфолошког или фонолошког уобличавања него творбени модел, јер ако бисмо и издвојили -stvo као суфикс, bе̌- не би могло бити творбена основа и не би могло бити морфемски део глагола въжатн; друго, он суфикс -stvo проширује вокалом -i- испред суфикса и притом објашњава зашто - тај вокалски елеменат омогућује „присоединят эту форму к основам, оканчивающимся на согласную”, те је тако настао продуктивни облик -ьstvo, али не каже како - одакле се то -і- (> -ь-) перинтегрисало и присајединило са првобитним -stvo. То нам А. Меје не каже, а и тешко би било наћи такву творбену основу од које би се перинтегрисало -і- (перинтеграцији би морала претходити и промена значења), и највероватније да првобитни облик суфикса -ьstvo није био -stvo. Коначно, није спорно да је суфикс -ьstvo „часто распространенний вторичным суффиксом -ьје - то нам уосталом недвосмислено потврђују многобројни старословенски примери (в. Цејтлин 1986: 176-191) - али није само -bstv-ьје давало „отвлеченные производные от имен”, јер и суфиксом -ьstvo су се изводиле апстрактне именице од именица, о чему сведочи, између осталог, обимна грађа из српског језика.

Александар Белић порекло суфикса -ство овако објашњава: „Наст. -ство са значењем апстрактним и колективним (вероватно наст. -тво комбинован са прид. наст. -ьскъıи после одвајања къlu, тј. -ьс-тво; могао би бити и -ьm+mво 
или сл.; словенског је порекла). Још је продуктиван” (Белић 2000: 139). - Осим што је словенског порекла и што је продуктиван, тачно је и то да у свом саставу има суфикс -тво, али је немогуће да је суфикс -ьство постао онако како А. Белић описује. Заправо, он је дао две хипотезе развитка суфикса -ьство: једна да је тај суфикс настао додавањем -тво на придевски суфикс -ьскъли „после одвајања -къли, тј. -ьc-тво”, а друга је да би „могао бити и -bm+mво”. Обе су те хипотезе неодрживе: прва - зато што се од придевског суфикса -ьскъли (одређени вид суфикса -ьскъ) никад не може одвојити -къли јер -къли напросто није морфема; друга - зато што веза $-b m+m в о$ не би уопште могла дати апстрактно значење, а камоли један од најпродуктивнијих суфикса за творбу именица са тим значењем.

В. Вондрак је, по нама (в. Стакић 1988: 161), најбоље објаснио постанак суфикса -bstvo (срп. -ство): „,.. an Adj., die mit -bsko-gebildet waren, wie z. B. dětbskb ist das Suff. -tvo getreten und aus dětbs(k)tvo entstand dětbstvo 'Kindheit'. Nach solchen Worten wurden dann auch von anderen Adj. usw. derartige Substantiva gebildet, wie z. B. bogatbstvo zu bogatb (es gab kein *bogatbskb)" (Вондрак 1924: 490). - Тачна је, пре свега, основна поставка да је суфикс -bstvo састављен из два дела - придевског суфикса -bsk- и именичког -tvo, те да је та перинтеграција извршена у прасловенском језику када је добијен именички суфикс -bstvo са основним апстрактним значењем. Ми не улазимо у то да ли је апстрактно значење добијено од придевске основе или је и именички суфикс -tvo имао такво (апстрактно) значење, за нас је важно само то да је у прасловенском језику добијен суфикс -bstvo са основним апстрактним значењем и да су га као таквог наследили сви словенски језици па и српски, у којем је добио велику продуктивност. Тачна је и Вондракова тврдња да се суфикс -bstvo додавао и на друге придевске основе, нпр. bogatbstvo (од bogatъ) мада није постојао придев *bogatıskъ. Мopa ce, дакле, претпоставити готов, перинтегрисан суфикс -bstvo који се додавао на придевску основу bogat-. Скренућемо пажњу на још један детаљ: када се од именица типа dětbstvo издвојио суфикс -bstvo, остала је именичка основа dět-. За нас је то путоказ како је суфикс -cmво (< ьstvo) постао продуктиван у творби апстрактних именица од других именица.

Мотивне речи и деривациони однос. Речено је већ да је суфикс -ство врло продуктиван у савременом српском језику. И у старословенском језику његова продуктивност је велика, а јавља се у два вида: -ьство: вогатьство и

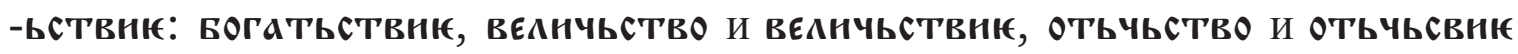
итд. (в. Цејтлин 1986: 176-191). Суфикс -ьствнњ је сложен, састављен од -ьство и -нє са истим (апстрактним) значењем. „По мнению большинства исследователей, слова на -ьствнє образовались под влиянием общеславянских слов на -ьство: суфф. -ьствнє - контаминация суфф. -ьство и -нє” (Цејтлин 1986: 190). Овоме треба додати и мишљење Хабургајева: „Принято считать, что в старейших кирило-мефодиевских переводах суффикс не осложнялся 
формантом -ню, который по происхождению является моравизмом, т. е. стал использоваться в период функционирования славянских переводов в Моравии. С течением времени (в ходе исторического развития церковнославянского языка вариант -ьств-нє получает все большее распространение, особенно - в восточнославянском изводе" (Хабургајев 1986: 123). У савременом српском језику нема сложеног суфикса -ствије, осим у неколико примера који су, заправо, црквенословенизми: чудествије, путешествије, молепствије, многолетствије (Николић 2000: 348).

Cтјепан Бабић пишући о суфиксу -ство, тврди следеће: „Sufiksom -stvo imenice su izvedene od imeničkih, pridjevnih, glagolskih, zamjeničkih, brojevnih i priložnih osnova" (Бабић 1986: 260). А што се тиче продуктивности појединих основа, Стј. Бабић додаје:,Plodna je sufiksalna tvorba od imeničkih osnova ..., a ostale su tvorbe slabo plodne ili su neplodne. ... Izvedenica sa sufiksom -stvo od pridjeva ima relativno malo. U građi ih se našlo pedesetak i već taj podatak kazuje da je tvorba od pridjeva slabo plodna. Pregled građe pokazuje da novih tvorenica iz 20. stoljeća nema, da je nekoliko novijih nastalo oko 1860. g., a ostale su starije tako da se može reći da je sufiks -stvo u ovoj kategoriji praktički neplodan. ... Od glagolskih osnova izvedeno je desetak imenica ... bístvo, dežúrstvo, jámstvo, násljedstvo, preustrójstvo, umórstvo ... Od ostalih osnova tvorenice su rijetke. Od brojevnih osnova izvedene su imenice dvójstvo, trójstvo, od zamjeničkih svójstvo, od priložnih mnóśtvo" (Бабић 1986: 266, 267). На основу овога јасно је да је суфикс -ство продуктиван само онда кад се додаје на именичке основе. То потврђује и наша грађа (из шестотомног Речника Матице српске). А потврђује и још нешто: међу мотивним именицама највише је оних које означавају особу, и то првенствено особу мушког рода. За Стј. Бабића „to je i razumljivo jer su im. m. r. u pravilu zastupnici vrste. Stoga imenice ž. r. dolaze kao osnove samo ako nemaju mocijskog para, a to su imenice koje imaju drugačije leksičko ostvarenje ili koje označuju osobine biološki ili sociološki svojstvene samo ženama: djèvojaštvo, pòsestrimstvo, prìmāljstvo, usidjelištvo ..." (Бабић 1986: 260).

Иван Клајн у вези са мотивним речима изведеница које имају и именице на -ство и придеве на -ски (а таквих је највише!), износи дилему, или псеудодилему, око одређивања творбених основа именица са суфиксом -ство. Ево шта он каже:

„Да ли је испред -ство именичка или придевска основа често није лако пресудити. Примера ради, Маретић 1963: 360 изводи јунаштво из јунак (преко јуначьство), а слично Лескин 1914: 299 каже да је дјевојаштво од именице (де̌војьчьство). Стевановић 1964': 537, напротив, убраја јунаштво, девојаштво, момаштво, нечовештво међу изведенице од придева. Оваква колебања су неизбежна, будући да велика већина именица са изведеницом на -ство има и придев на -ски / -чки (уп. Бабић 1991: 278), а фонетске алтернације су исте с једним и с другим суфиксом. Пошто нема разлога да именице на -ство сматрамо секундарним или мање важним од придева на -ски, ми ћемо их третирати као деноминалне где год постоји именица с датом основом" (Клајн 2003: 185, 186). 
Овде И. Клајн у много чему није у праву: 1) Да ли је испред -ство именичка или придевска основа, лако је „пресудити”, јер се то види из творбеног значења и творбеног односа именица на -ство са мотивним именицама. 2) Маретић и Лескин с правом изводе јунаштво из јунак (јер јунаштво значи „особина коју има јунак” РМС), М. Стевановић, истине ради, именице девојаштво, момаштво изводи и од именица и од придева (Стевановић 1970: 511, 512), што, разуме се, није исправно јер су обе изведенице од именичке основе: девојка, момак. 3) „Оваква колебања” не само да нису „неизбежна” него их и нема иако „велика већина именица са изведеницом на -ство има и придев на -ски/-чки" (-чки је фонемски завршетак! Није ни суфикс ни аломорф суфикса -ски). А шта смета именицама на -ство што се од њихових мотивних именица граде и придеви на -ски? 4) Неће бити да су фонетске алтернације „исте с једним и с другим суфиксом: упор јуначки и јунаштво и сл. 5) Ако уопште треба коментарисати, не одређује се да ли су неке изведенице, у овом случају - именице на -ство, деноминалне или деадјективне по томе што „нема разлога да именице на -ство сматрамо секундарним или мање важним од придева на -ски" него на основу творбеног дефинисања изведеница и на основу тога успостављеног деривационог односа изведених и мотивних речи.

Михаило Стевановић међу именицама изведеним суфиксом -ство од придева као што су блаженство, богатство, детињство, достојанство, неваљалство, пијанство, проклетство, мајчинство и сл наводи и девојаштво, јунаштво, момаштво. Да ли с правом? Свакако не, а ево зашто. Прво, суфикс -bstvo је постао у прасловенској епоси од придевског -bsk- и именичког -tvo $(-b s(k) t v o)$. После перинтегрисања придевског -bskъ остајала је именичка основа (упор. dět-bskъ + -tvo - dět-bstvo). Тако добијен именички суфикс додавао се на друге именичке основе, па и придевске (упор. bogatbstvo : bogatъ), али не и на придеве од којих је постао, на придеве са суфиксом -bskъ. Погледајмо сада и семантичку страну. Од придева типа богат, проклет, блажен и сл. помоћу суфикса -ство изведене су именице богатство, проклетство, блаженство које значе особину коју карактерише придев у основи. А именице које је М. Стевановић ставио у групу деадјектива имају ова значења: девојаштво „доба девојачко, девовање”, јунаштво „1. особина онога који је јунак. 2. јуначко дело”, момаштво „1. момачко, младићко доба. 2. момачка снага и окретност”. Нису то само апстрактне именице: девојаштво је доба у животу жене, живот девојке и карактеристика тога периода у животу жене; јунаштво је осбина јунака, дело које је учинио јунак; момаштво је доба у животу мушкарца, живот момка, снага момка" и сл. Најкраће речено, ове и њима сличне именице означавају нешто што се односи на именице у основи. Напоредо са именицама на -ство постоје и придеви на -ски. „Прасловенски суфикс -bskъ је суфикс односних придева који је могао означавати групну или категоријалну припадност, а није имао индивидуалнопосесивно значење” (Маројевић 1985: 95). И док у 
руском језику, на пример, придеви на -sk- поред основног односног значења, у зависности од контекста, могу изражавати припадност појединачном лицу, у српском језику придеви тога типа могу имати само односно-квалитативно значење (в. Маројевић 1983: 159-175). На крају, да су се именице на -ство градиле преко придева на -ски, то би било свеобухватно, тј. где год постоји придев на -ски од њега би се градиле именице на -cmво, а то значи да не би било именица типа бачва́рство ( упор. бачвар и бачварски), бећа́рство (бећар и бећарски), вуна́рство (вунар и вунарски), друга́рство (другар и другарски), зана́тство (занат и занатски) и др.

Суфиксни деривати и аломорфи. Суфикс -ство у српском језику има и свој аломорф -тво. Иван Клајн га погрешно издваја и погрешно бележи као -штво. „То може бити после основа са завршетком на -к (рођаштво, чов[j]ештво, власништво), на -г (друштво, мноштво), на -и (тужилаштво, удовиштво), на -ч (издаваштво, стрељаштво), на -ж (лупештво), на -з (витештво), а наравно и после основа које већ имају -ш на крају (секташтво, усташтво, мекуштво)" (Клајн 2003: 185). - У свим овим и многим другим сличним изведеницама аломорф је -тво, а $m$ је део творбене основе. То је добро уочио и објаснио М. Стевановић: међу именицама на -ство „има повећи број именица у којих немамо наставак -ство, већ се оне завршавају на -штво. Али сугласник $ш$ овога завршетка припада општем делу тих изведених речи, а не њихову наставку; он је постао од неког задњонепчаног сугласника којим се завршавао тај део и који је, налазећи се у предгласовном положају где се палатализовао, постао сугласником $z$. Ако је то био сугласник $x$, као у cuромах $b^{-}$, он је једноставно прешао у $z$, а ако је пак био г, као у многь-, или $\kappa$, као у јунакь-, прелазио је прво у ж, односно у ч" (Стевановић 1970: 512). - Дотле је све тачно, али надаље се и код њега јавља непрецизност: „А ова последња два предњонепчана сугласника у таквом положају су се упрошћавала и свела се коначно на $u$, иза кога је сугласника $c$ од наставка -ство нестало, да се у резултату свих тих гласовних промена место наставка -ство добије завршетак -штво" (Стевановић 1970: 512). - Ваља приметити, прво, да се два предњонепчана сугласника (ж и ч) нису у том положају „упрошћавала и свела се коначно на $w$ ”. Сугласник ж се није упрошћавао, него се напросто

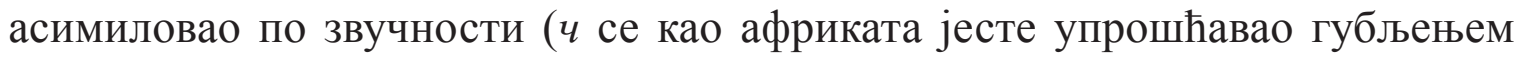
експлозивног елемента, али не испред $c$ него испред $m$ ). Даље, у јуначьство није се $c$ из суфикса -ство губило иза $u$ него иза 4 , а само $q$ се испред $m$ (у групи -чm-) упростило у $ш$.

Дакле, аломорф је -тво и јављао се иза различитих завршетака творбене основе услед различитих гласовних алтернација. Све ћемо то показати на прикупљеном материјалу и, разуме се, у главним цртама:

с : ф аутонома́штво, велика́штво, зелена́штво, кајака́штво, лакта́штво, парола́штво, робија́штво, ӱсташтво и уста́штво, цуиција́штво; 


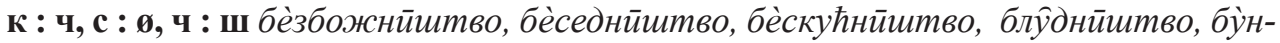

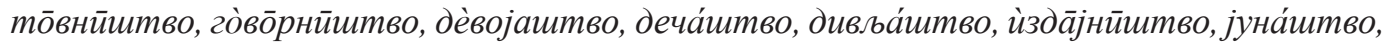

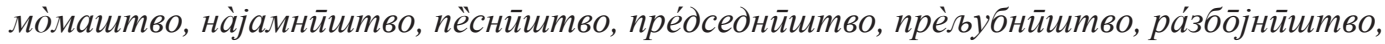
ра́сипнӣштво, сеља́штво;

г : ж, ж : ш, $\mathbf{c}: \boldsymbol{\varnothing}$ бо̀штво, дема̀гоштво, књйштво и књйштво, мно̀штво, уेбоштво и ӱбоштво, хѐриештво;

$\mathbf{x}: \mathbf{ш ,} \mathbf{c}:$ : мона́штво и моेнаштво, сиро̀маштво и сирома́штво;

ц : ч, с : б, ч : ш блѝзанаштво и близа̀наштво, вӓралаштво, вла̀далаштво, знӓла-

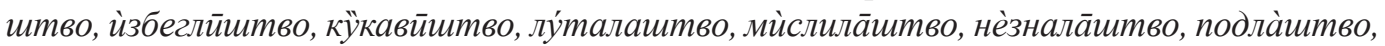
правобра̀нилаштво, прѐгала̄итво, про̀палӣштво, пйзава̄итво, ро̀нилаштво, са̀маштво, са́нала̄штво, спа̀сила̄штво, ста̀ралаштво, ства̀ралаштво, ту̀жилаштво, у̀дворииштво, удо̀виштво, чѝталаштво;

з $(<\Gamma):$ ж, ж : ш, с : ø вйте̄щтво, кне́штво;

с : $, \mathbf{ч}:$ : ш кошара́штво „кошарачки обрт, занат, плетење кошара” (: кошарач), прона̀лаза̄штво и проналаза́штво;

ж : ш, с : п лу́nештво, ста́лештво.

Сви ови и њима слични примери потврђују аломорф -тво који је настао од основног суфикса -ство у датим условима, тј. услед набројаних сугласничких алтернација. И то је једини аломорф суфикса -ство. Именице њиме изведене имају исто значење као и именице са основним суфиксом -ство.

За разлику од аломорфа, суфиксни деривати настају перинтеграцијом као последица унутрашњег богаћења значења изведеница са суфиксом -ство. И никад не значе исто што и изведенице са основним суфиксом. Иван Клајн их назива сложени суфикси, а за нас су деривати суфикса јер су настали променом деривационог односа и перинтеграцијом. Суфикс -ство има додуше и један сложени суфикс, који је чак и продуктиван, али не у српском него у старословенском језику - суфикс -ьствню: вогатьствнћ, велнчьствнћ, отьчьсвнє и сл. Настао је контаминацијом двају суфикса са истим, апстрактним, значењем: -ьство и -ню. Деривати суфикса настају на други начин - не контаминацијом двају истозначних суфикса, него променом значења и перинтеграцијом. То је убедљиво и аргументовано објаснио Радосав Бошковић на материјалу српског језика у вези са моционим суфиксом -ица и његовим дериватом -арища. Најкраће речено, овако: Однос арица : ар „могао је првобитно значити само однос femininum-а према maskulinum-y". Данас, међутим, именице на -арица имају и друга значења, нпр.: овчарица поред „женска која чува овце” (masc. овчар) значи и „колиба за овце”. У овом новом значењу реч се не дели на морфолошке елементе овчар-ица (као код моционог значења) него на овч-арица. Ново значење не омогућава везу суфиксу -ииа са основном речи - „та је веза могућна само преко његова деривата -арица". „Према томе” - закључује Р. Бошковић - „развитак значења̂ код наставка ica у овим приликама прати свугде и стварање његових деривата, и о промени првобитног основног значења његова - може се само на основу њих и говорити" (Бошковић 2000: 221, 222). 
Све се ово може показати и на примерима суфиксних деривата именичког суфикса -ство: док је гљива́рство било у деривационом односу са гљивар „онај који бере и продаје гљиве”, могло је значити само једно: посао гљивара, тј. брање и продају гљива. Али када гљиварство значи „грана науке, знаности која се бави проучавањем гљива", не може се никако довести у везу (деривациони однос) са гљивар него само са гљива. Или: кад је говеда́рство значило чување говеда, посао говедара, могло је бити само у деривационом односу са говедар „онај који чува говеда", међутим, у значењу „гајење говеда као привредна грана", изведеница говедарство не доводи се у везу са говедар него са говед(a) и суфикс није -ство него -арство. Исто тако: кад се изведеница коза́рство разложи на творбене морфеме козар-ство, у деривационом је односу са коेзар , пастир који чува козе” и има значење „посао козара, чување коза", али у значењу „гајење коза као привредна грана сточарства” изведеница козарство може бити само у деривационом односу са коз(а) и творбено се разлаже на морфеме коз-арство. Као што се види, код свих тих (и њима сличних) именица ново значење доводи до новог деривационог односа, према новој мотивној речи, и до новог морфемског разлагања на творбену основу и наставак. Другим речима, именице са суфиксом -ство су у свим овим и сличним случајевима значењски везане за мотивне речи nomina agentis ca суфиксом - ap. Нова значења настају у новим деривационим односима - не са изведеницама на - ap него са речима од којих су начињене - и неминовно траже нову морфемску прерасподелу - нису изведене суфиксом -ство него -арство. Тако је и код осталих деривата суфикса -ство - да се не понављамо. Остаје само да их наведемо и потврдимо примерима из Речника Матице српске.

-арство: брода́рство а. привредна грана која обавља превоз путника и робе водом; рад са бродовима, бродарење. б. бродови, бродовље; бродарска струка; бујича́рство рад на уређењу бујица; вина́рство с 1. наука о производњи и прерађивању вина. 2. привредна делатност, грана привреде која се бави производњом и прерађивањем вина; винограда́рство с пољопривредна грана која се бави гајењем винограда; наука о гајењу винограда; воћа́рство и вӧћа̄рство с 1. гајење воћа. 2. грана привреде која се бави гајењем воћа; дрва́рство с наука о дрвету; живина́рство с гајење живине као привредна грана; коња́рство с узгајање коњ а као грана народног господарства, народне привреде; кудеља́рство, ијек. кудјеља́рство с производња кудеље као грана привреде; ку̀нића̄рство и кунића́рство с одгајаґе кунића као привредна грана за добивање меса и крзна. лана́рство с гајење и прерада лана; лѝвада̄рство и ливада́рство с пољопривредна грана у оквиру сточарства која се бави гајењем и искоришћавањем ливада; маслина́рство с гајење маслина као грана привреде; млека́рство, ијек. мљека́рство, с производња млека и млечних производа као грана привреде; новча́рство с новчани послови, новчане ствари, трговање новием; овча́рство с гајење, узгој овациа као привредна грана; перада́рство 
с гајење перади; пилана́рство с прерада дрвета у полуфабрикате помоћу пилана; платна́рство с индустрија платна; поврћа́рство с = повртарство. гајење поврћа као грана пољопривредног господарства, баштованство; пчела́рство с гајење пчела (ради добијања меда и воска) као привредна грана; рӓна̄рство и рана́рство с вештина лечењь рана, видарство; свила́рство с рад на гајењу свилених буба, предеюу и ткању свиле, свиларска индустрија; сола́рство с производюа соли; стабла́рство с грана привреде која се бави гајењем шуме; стакла́рство с занатска и привредна грана која се бави израдом и обрадом стакла, стаклене робе; старина́рство с 1. трговина старинама. 2. испитивағе старина, археологија; цвећа́рство, ијек. цвјећа́рство, с грана пољопривреде која се бави гајењем извећа, изетарство; шљива́рство с агр. гајење иљива; пољопривредна грана која се бави гајењем иљива; шума́рство с пољопривредна грана која се бави гајењем и коришћењем шума; наука о гајењу иума;

-анство: велича̀нство и велича́нство 1. узвишеност, величина. 2. титула који се даје владару; владича̀нство и владича́нство с 1. служба и достојанство владике. 2. у црквеној управи подручје којим управља владика, епархија; девича́нство и девича̀нство стање девице, полна неповређеност, невиност; језича́нство с индив. укупност језичног блага; ку̀ћа̄нство и кућа́нство с 1. оно што се у пословима односи на кућу, кућни послови, кућно господарство. 2. кућна имовина, покућство; месија́нство с месијанизам; спасилачка, избавитељска улога; мужа̀нство с поет. доба мушке зрелости; достојанственост и одважност зрелог човека; мухамеда́нство с исламска вероисповест, ислам, муслиманство; по̀кућа̄нство и покућа̀нство с покућство; полубожа̀нство с полубог. [полубог 1. у античкој митологији божанство нижег реда ... 2. врло моћан човек]; пророча̀нство и пророча́нство с = пророштво а. према схватању разних религија способност прорицања будућих догађаја као надахнуће божје. б. оно ито је пророковано, предсказано да ће се догодити в. предвиђање онога што ће се догодити на основу познатих чињеница, из којих се може закључити будући развитак појава, догађаја, прогноза; сведоча̀нство и сведоча́нство, ијек. свједоча̀нство и свједоча́нство, с 1. a. податак, чињеница или докуменат којим се утврђује истинитост нечега, доказ, потврда нечега. б. текст, исправа са одређеним подацима који могу послужити као званични доказ или потврда за нешто, докуменат. 2. писмено уверење о постигнутом успеху које школа на крају године даје ученику. 3. исказ, изјава, сведочене, тврђење; су̀пружанство с брачно стаюе, супружништво; човеча̀нство, ијек. човјеча̀нство, с сви људи, људски род, свет; шепртља́нство с особина онога који је шепртља, неспретност, неумешност; невешт, неспретан поступак, неспретно пословање, иепртььанија;

-инство: брӓтйнство 1. в. братимство. 2. братовитина. 3. наслеђе од брата; га̀здйнство и газди́нство с 1. имање; својина. 2. а. привреда. б. 
пољопривредно имање, добро; го̀стйнство с гостински односи, пријатељски односи; пријатељьство [РСАНУ]; дёдйнство заст. 1. в. дедовина (1) [имање наслеђено од дедова, дедовско наслеђе, наследно имање]. 2. в. дедовина (2) [завичај, домовина, отаибина]; жѐнйнство с 1. имовина коју жена уноси у брак или касније наследи, мираз. 2. женске одлике, женственост; маิјчйнство и мајчи́нство с в. материнство; ма̀терйнство и матери́нство с 1. осећање мајке према детету; стағе жене мајке; трудноћа. 2. имање наслеђено од мајке; мӓћехйнство с положај жене-маћехе; особина маћехаิ, немилосрдност, грубост; нӓшйнство с оно што је наше [ Вук $P j$. ]; оेчйнство и очи́нство с 1. крвна веза између оияа и деще, порекло од ойа. 2. очевина; па̀шйнство и пӓшйнство с 1. чин, достојанство паше. 2. наслеђе од паше; сёстрйнство с 1. део који сестра поред браће добива као наследство. 2. склапање посестримства, сестримљење; пријатељска веза међу посестримама или блиским женским особама уопште, присно другарство; Һи́фтинство с ћифтинско схватане и поступање.

-аштво: голема́штво особина онога што је големо; фиг. лудило величине (: голем); стӓра̄штво с питања (друштвена, медицинска и сл.) везана за старост, старе особе (: стар); стреља́штво с а. стрељање. б. спортска грана у којој се из пушке или пиштоља гађ а у нарочите мете (: стрељ-ати).

Наша грађа не потврђује постојање других деривата суфикса -ство, али не зато што „наспрам њих као основа увек постоји nomen agentis на -тељ, на -лаи односно на -āp" (Клајн 2003: 185). Наиме, по нама, није услов за настанак суфиксних деривата да наспрам њих не постоје nomina agentis него да је изведена именица развила ново значење које је у творбеној анализи не доводи у везу са nomina agentis него са основним именицама од којих су nomina agentis изведене. Конкретно: живинарство је изведено суфиксом -арство не зато што не постоји реч живинар него зато што творбено значење (,гајење живине као привредна грана") не дозвољава да се изведеница живинарство доведе у везу са живинар него само са живин(а). Узгред да приметимо, не објашњава И. Клајн настанак „сложеног суфикса” -анство исправно: није -анство пренето из речи достојанство, пијанство јер су те изведенице у творбеном односу са придевима достојан и пијан и само са њима, а тај однос издваја и може да издвоји само суфикс -ство. Иначе, да и то нагласимо, за издвајање суфиксних деривата није довољно само ново значење. Примера за то има много међу именицама на -ство: господа́рство с 1. власт, влада; владање. 2. а. управљање имањем, добрима, економијом. б. привреда (кућна, пољска, иумска и др.). в. имање, посед (обично земљишни); жанда́рство с 1. а. служба ужандармерији. б. жандармерија. 2. особина жандар(м)а, суровост, бездушност и сл. И овакве именице су могле добити и добиле су нова значења, али се из њихових мотивних речи не може издвојити - $а р$ и перинтегрисати са -ство. Два су, дакле, по нама, услова неопходна да би се издвојио и осамоста- 
лио суфиксни дериват: један је да дође до промене значења изведенице и да то ново значење захтева нови деривациони однос, а други је да је мотивна реч изведенице такође, за наше језичко осећање, изведена реч. Тако се дериват -арство могао издвојити из бродарство, коњарство, шумарство и сл., али не из господарство, жандарство и сл. Притом ништа не смета што у језику постоје именице бродар, коњар, шумар, важно је само да ново значење не доводи изведенице бродарство, коњарство, иумарство у деривациони однос са њима него са основним речима брод, кою, шума.

Суфиксни синоними. Именице изведене суфиксом -ство имају према себи подоста изведеница са различитим суфиксима а од исте основе. Или, исто то али друкчије речено, суфикс -ство има синонимне суфиксе са истим или сличним значењем: -ypa: адвока́тство - адвокату́ра (: адвокат), литерату́ра - литера́тство (литерат), команданту́ра - команда̀нтство (командант); -итина: балка́нство - балка́нштина (Балкан), сирома́штво - сирома́штина (сиромах), лука́вство - лука́вштина (лукав), прља́вство - прља́вштина (прљав), лу́пештво - лу́пештина (лупеж), грубија́нство - грубија́нштина (грубијан); -изам: банди́тство - бандитѝзам (бандит), ванда́лство - вандалйзам (вандал), епикуре́јство - епикурейзам (епикуреј), идио̀тство - идиотѝзам (идиот), или́рство - илирѝзам (илир/и/), паразѝтство - паразитѝзам (паразит), патрйотство - патриотѝзам (патриот/a/), радика́лство - радикалѝзам (радикал), херо́јство - херойзам (херој); -ина: бёговство - бёговина (бегов), -je: безве́рство - бѐзвёрје (без вере), бѐзумство - бѐзуммље (без ума), бешчи́нство - бѐшчйње (без чина), лицеме́рство - лицѐме̄рје (лицемер); -ија: брава́рство - брава̀рија (бравар), кола́рство - кола̀рија (колар), лонча́рство лонча̀рија (лончар), мегало̀ма̄нство - мегалома̀нија (мегаломан), решета́рство - решета̀рија (решетар), стола́рство - стола̀рија (столар), тира́нство - тира̀нија (тиран/ин/), - $\bar{m} m$ : ѐпископство - еписко̀па̄т (епископ); -лук: женска́рство - женска̀рлук (женскар), хр̀суство хрсу̀злук (хрсуз), чапку́нство - чапку̀нлук (чапкун); -о̄cm: лако́мство - лӓкомо̄ст (лаком), ле́нство - лёно̄ст (лен), прља́вство - пр̈љаво̄ст (прљав), свирѐпство - свѝрепо̄ст (свиреп), својегла̀вство - својѐглаво̄ст (својеглав), сувере́нство - су̀верено̄ст (суверен), -ерија: полтро́нство - полтронѐрија (полтрон).

Као што се види, овде смо издвојили само творбене синониме од исте основе, исте мотивне речи, а изведене именице имају исто или слично значење са изведеницама помоћу суфикса -ство. Овом приликом не улазимо у замршене теоријске проблеме синонимије, нити пак у различите поделе и врсте синонима (о томе в. Драгићевић 2007: 244-264). Желели смо само да потврдимо постојање и других изведеница (са другим суфиксима) од исте творбене основе, а значе исто или слично што и оне са суфиксом -ство. Ова синонимност је различито приказана у РМС (при чему не искључујемо ни манир лексикографа, напротив): 1) адвока́тство с адвокатура, ванда́лство с вандализам, идио̀тство с идиотизам, или́рство с илиризам, лицеме́рство, 
ијек. лицемје́рство с лицемерје; 2) балка́нство с и балка́нштина ж в. балканизам; 3) сиро̀маштво и сирома́штво $\mathbf{c}$, сиро̀маштина и сирома́штина ж 1. стање онога који је сиромах, немаштина, оскудица неопходно потребних средстава за живот, беда. 2. недовољност, оскудииа у чему, оскудност, безначајност чега. 3. сиромашан, убог, жалостан спољашни изглед. 4. сиромаси, сиротиња. 5. сиромашна имовина, сиротиња [Свих 5 значења! - МС ]; 4) банди́тство с 8 . бандитизам, бѐзумство с рус. в. безумље, лако́мство с в. лакомост, ле́нство, ијек. лијѐнство, с в. леност; 5) епикуре́јство с $=$ епикуреизам, херо́јство $\mathbf{c}=$ хероизам, брава́рство $\mathbf{c}=$ браварија, женска́рство $\mathbf{c}$ = женскарлук; 6) паразѝтство с паразитизам (2).[„,појава кад неко живи од туђега рада, на рачун другога"]; 7) патрйотство с заст. в. патриотизам; 8) радика́лство с. радикалност; радикализам; 9) бёговство с звање и достојанство бега; земьа и област једног бега, беговина, беглук, полтро́нство с својство и поступци полтрона, полтронерија.

Значења. Основно значење изведених именица суфиксом -ство од именичких основа је особина појма означеног мотивном речи. За нас је ово разумљиво с обзиром на порекло суфикса -ство (од односних придева на $-s k b$ и именичког суфикса - $t v o$ ). Касније су ове именице развиле и многа друга значења - апстрактна а и конкретна. Тако ћемо их и поделити - прво на две основне групе: са апстрактним и са конкретним значењем, а у оквиру њих - на неколико различитих група са блиским, сличним значењима.

I Апстрактна значења: 1. о с об и на: а) особина особе, појединия: блѐферство, богомо́љство, ведо̀гоњство, велика́нство, ветропи́рство, грубија́нство, декадѐнтство, дисѝдентство, друга́рство, женска́рство, зулумћа́рство, идио̀тство, интрйганство, исто̀рича̄рство, јара́нство, каћипе́рство, комедйјанство, лицеме́рство, на̀здравича̄рство, позе́рство, политика́нтство, полтро́нство, полута́нство, профите́рство, пу̀ргерство, рутине́рство, свезнада́рство, сйлеџйјство, скӧројевићство, слаби́ћство, слугера́њство, сна̀га̄то̄рство, сплетка́рство, трубаду́рство, фразе́рство, фука̀рство и фу̀карство, халуцйна̄торство, херо́јство, хӧхштапле̄рство, хулига́нство, чапку́нство, џѐнтлменство, шарлата́нство, ше́ретство и шѐретство, шкр̀тича̄рство, шпекула̀нтство, шпију́нство, штре́берство; б) фиг., метафорична значења: ајги́рство с особина ајсира; фиг. похотљивост, путеност. звѐрство и звёрство, паразйтство, ско̀тство, животи́њство и живо̀тӣњство 2. дивљаштво, суровост, грубост; в) својство, одлика: арба̀наштво, балка́нство, ванда́лство, јевре́јство, мађа̀рство и мађа́рство, талија́нство, хрва́тство; г) немање нечега: бѐзвёрство и безве́рство, бѐзумство; д) нагон: месожде́рство; Ђ) дуx, карактер: наполео́нство, револуциона́рство, русофи́лство; е) однос, веза: по̀братймство и побрати́мство, покро̀витељство и покровите́љство, по̀сестрймство, ро̀дбинство и рӧдбинство, ро̀дитељство, са̀братство; ж) поступщии: пусто̀ло̄вство и пустоло́вство, факи́нство; з) политичка припадност: радика́лство, реакциона́рство; 2. стањ е: a) стағе 
у држави, друштву: бескра́љство; б) стање, живот: бећа́рство, бое́мство, буржу́јство, зётство, черга́рство; в) стање, својство појединиа: бӧга̄љство, визиона́рство, гола́ћство, дѐмбелство, пӧдстана̄рство и подстана́рство, поко́јство, сироेтйњство и сироти́њство, сӱстана̄рство и сустана́рство, убога́рство, циви́лство, шѐгртство; г) част, титула: гро̀фовство, ло̀рдство; д) дух и схватане: догма̀тича̄рство, лѐвича̄рство, лутера́нство, мађаро́нство; ђ) припадност: дружавља̄нство и државља́нство; е) доба живота: млади́ћство; ж) вероисповест: муслима́нство, патаре́нство, унѝјатство; з) став: опозициона́рство; и) подјармљеност, потчињеност: ро̀пство; 3 . p а д: а) позив, посао: адвока́тство, админйстраторство, аквизите́рство, бажда́рство, баштова́нство, вида́рство, врата́рство, гӱса̄рство и гуса́рство, дво̀ра̄нство, драгу̀ља̄рство и драгуља́рство, живоде́рство, зуба́рство, ка̄мата̄рство, камена́рство, каскаде́рство, књйжнича̄рство и књижнича́рство, коба̀сича̄рство, ко̀нобарство и ко̀ноба̄рство, контроло́рство, крчма́рство, луга́рство, менаџе́рство, мисиона́рство, млӥна̄рство, нӓднича̄рство, на̀дрилека̄рство и надрилека́рство, новина́рство и нӧвина̄рство, одго̀јитељство, пѐча̄лба̄рство и печалба́рство, пива́рство, пи́внича̄рство, писа́рство и пйса̄рство, подрума́рство и по̀друма̄рство, покућа́рство и по̀кућа̄рство, по̀сластича̄рство и посластича́рство, пошта́рство, ра̄та̄рство и рата́рство, риба́рство и рӥба̄рство, руда́рство, свашта́рство, секрета́рство, сладича́рство, сплава́рство, струга́рство, фарба́рство, хӱса̄рство и хуса́рство, чо̀банство и чоба́нство, штампа́рство; б) звање и достојанство: архимандри́тство, барјакта́рство, бёговство, бригади́рство, влада́рство, жупа́нство, ѝгуманство и ѝгума̄нство, канцела́рство, кардина́лство, команди́рство, комеса́рство, мандари́нство, марша́лство, муфти́јство и му̀фтйјство, паิпство, плёмићство, пӧджупа̄нство, про̀фесорство и професо́рство, рёкторство, рйтерство, свѐтитељство, сѐна̄торство, серда́рство; в) занат: бачва́рство, брава́рство, ваља́рство, вуна́рство, грнча́рство, дрво̀дёљство, зида̀рство, злата́рство, јувели́рство, клѐса̄рство и клеса́рство, клобуча́рство, ковина́рство, кожуха́рство, кола́рство, ко̀рита̄рство и корита́рство, корпа́рство, котла́рство, крзна́рство, ли́внича̄рство, лонча́рство, меса́рство, ножа́рство, обућа́рство и о̀бућа̄рство, опанча́рство и ӧпанча̄рство, плета́рство и плѐта̄рство, рука̀вича̄рство, сапуна́рство, седла́рство, стола́рство и стӧла̄рство, тапета́рство, теса́рство, тока́рство, ћилима́рство, ужа́рство, цигла́рство, чӓсо̄внича̄рство и ча̀со̄внича̄рство, чизма́рство, чйпка̄рство и чипка́рство; г) учење: бого̀мйлство, богу̀мйлство, епикуре́јство, мо́јсијевство; д) уметност: ваја́рство, кипа́рство, слика́рство и слйка̄рство; ந) вештина: врача́рство, гата́рство, јѐдрилича̄рство, мађио̀нича̄рство, о̀ра̄торство, падобра́нство; е) чин: генера́лство, капета́нство, ка̄пла̄рство и капла́рство, мајо́рство, офици́рство, пӧдба̄нство; ж) дужност у некој ситуацији: девѐрство и деве́рство; з) служба: делово̀ђство и дёловођство, дйректо̄рство, кӧнзулство и коิнзулство, па̀зите̄љство и пазитѐљство, панду́рство, хӱса̄рство и хуса́рство, цёнзорство и цеิнзорство; и) поступак: капиту̀ланство и капитула̀нство, лйхва̄рство и лихва́рство, мегалома́нство и мегало̀ма̄нство, 
па̀нича̄рство, штеточи́нство и штёточйнство; j) предузимљивост: но̀ва̄торство; к) склоност: па́рнича̄рство; л) саучесништво: партне́рство и па̀ртне̄рство; љ) врста спорта: планина́рство, смӱча̄рство; м) владање: рѐгентство.

II Конкретна значења: 1.3 и рн о, ко лекти вно: библиотека́рство 2. зб. библиотекари, божја̀штво 2. зб. божјаци, бра̄тство и бра̀тство. 4. a. цркв. калуђери, редовници једног манастира, самостана или истог калуђерског, редовничког реда, брита́нство с 1. зб. Британци, водство с $=$ вођство 2. зб. скуп вођа, грӓђа̄нство и грађа́нство с 1. зб. грађани једног града, дру́штво 2. ограничен слој људи који сачињавају ужу заједнииу на основу сталешких, класних и сл. разлика. 3. скуп ьуди који живи заједно или се често скупља ради заједничког посла, забаве, разоноде и сл. 4. удружење или заједница људи који су себи поставили какав заједнички задатак или цฺиљ, а везани су међу собом друштвеним приликама: акционарско , деоничарско , спортско ... 5. рој пчела, ѐпископство $\mathbf{c}=$ епископат. [1. скуп епископа у земљи], жѐнство 2. зб. жене, женски свет, животи́њство и живо̀тйњство 1. зб животиње, животиғски свет, жйдовство б. (Жидовство) зб. Жидови, југославе́нство 2. (Југословенство) скуп свих Југославена, ју̀нкерство 2. скуп јункера, ку́мство 3. зб. кумови, људство с 1. а. људи у оквиру неке заједнище, (целине, скупа), неке војне или др. јединице, људски састав; жива сила. б. људи који служе на одређеном оруђу, машини, броду и сл., посада. 2. људско мноштво, народ, свет. 3. заст. а. људски род, човечанство. б. народ, начија, по̀по̄вство 2. скуп попова, свештенство, ренега́тство 2. зб. ренегати, славе́нство б. (Славенство) сви Славени, срппство б. (Српство) српски народ, сви Срби, стареши́нство 2. а. скуп старешина, руководиоци, руководећи кадар, сту̀дентство с 1. зб. студенти, су̀седство и су́седство, ијек. сӱсједство и су́сједство 2. зб. суседи, у̀кућа̄нство с 1. зб. укућани, хришћа́нство и хрѝшћа̄нство 2. зб. хришћани, хришћански свет, заједница хришћана, цйнцаррство с 1. цинниарски свет, циинщарски народ, чла̀нство 2. скуп чланова једнога друштва.

ду̀хо̄внйштво и ду̀ховнйштво 1. скуп духовника, свештенство, ђа́штво 1. зб. им. од Ђак, земљо̀ра̄днйштво зб. земљорадници, исељени́штво б. зб. исељеници, коза́штво зб. козаии, ку̀лаштво и кула́штво кулаџи; мона́штво и мо̀наштво 1. зб. монаси, на̀дсто̄јнйштво и на́дсто̄jнйштво б. скуп, више надстојника, на̀учења̄штво и научења́штво 2.. зб. научењаци, петоколона́штво 1. скуп петоколонаша, праิвнйштво 2. зб. правниции, раิднйштво зб. радниции, струัчња̄штво 2 зб. стручњаии, трезвења́штво 2. трезвењаци, у̀реднйштво 1. група људи који врше уређивање новина ..., ӱсташтво и уста́штво 2. мноштво, велики број усташа, чӓснйштво зб. скуп часника, чётнйштво 2. зб.четниии; 2. П о с е д, и м а њ е: властели́нство с 1. властелински посед, вла̀стёлство с = властеоство 1. властелски посед, господа́рство 2. в. имаъе, посед (обично земьишни), губѐнна̄торство 2. област, покрајина којом управља губернатор, домаћи́нство 2. дом као привредна, економска чүелина, цаิрство 2. цуаревина (1); 
хѐрцештво област којом влада хериег; 3. С т а л е ж: властели́нство 2. сталеж властелина, властелини, вла̀стёлство с $=$ властеоство 2. властелински сталеж, госпо̀дство 2. господа, господска класа, грӓђа̄нство и грађа́нство 2. грађанска, буржоаска класа, грађански сталеж, трेговйнство и тргови́нство 2. трговачки сталеж, трговци, у̀читељство и учите́љство с 1. учитељи (као колектив), учитељски сталеж;

редовни́штво б. редовнички сталеж, сеља́штво сељации као друштвени сталеж, класа, ста́лештво заједнииа појединих сталежа, чиновни́штво и чѝно̄внйштво 2. зб. чиновнички сталеж, чиновници, чйталаштво скуп читалаца, читаоии; 4. У с т а н о в $\mathrm{a}$, о б ј е к а т: кмётство и кмѐтство 2. установа средњовековног порекла и феудалних сочијалних односа ... уго̀ститељство и угостите́љство 2 угоститељски објекти.

заповедни́штво 2. установа која издаје заповести, на́дзо̄рнйштво и на́дзорнйштво 2. установа канцеларија, на̀дсто̄јнйштво и на́дсто̄јнйштво в. канцеларија, уред у коме се обављају надстојнички послови, на́меснйштво 2. намесничка канцеларија, намеснички уред, поверени́штво 1. установа којој је на челу повереник, прѐдста̄внйштво 2. установа која заступа нечије интересе, таิјнйштво установа којој је на челу тајник, тајнички уред.

Изведенице суфиксом -ство чије су мотивне речи придеви (описни придеви) увек значе особину приписану особи а дефинисану мотивним придевом: богатство (: богат), лукавство (лукав) и сл. Таквих изведеница нема много. О њима је у раду већ било речи и било би сувишно понављати или што додавати.

Закључне напомене. Именице изведене суфиксом -ство у савременом српском језику имају велику продуктивност, што поред бројности показују и широка лепеза значења и осамостаљивање нових деривата основног суфикса. Најчешће су у деривационом односу према именицама, што је разумљиво и с обзиром на порекло овог суфикса (на односне придеве са суфиксом -skb додат је именички суфикс -tvo: dět-sk- + -tvo $>$ dět-s(k)tvo). Такво порекло објашњава и основно значење особина својствена мотивној именици, из којег су се временом развила и многа друга значења. Када су мотивне именице и саме биле изведене, променом значења долазило је до промене деривационог односа и перинтеграције. тј. издвајања суфиксних деривата: говедарство у значењу „чување говеда, посао говедара” творбено се доводи у везу са говедар „чувар говеда" и морфемски се разлаже на говедар-ство, а у промењеном значењу „грана привреде” мења се и деривациони однос и творбена структура: говедарство и сл. Суфикс -ство има и аломорф -тво (јунаштво, витештво и сл.), настао као последица различитих гласовних алтернација, а понекад га погрешно издвајају као -штво (мада је -штво увек и само фонемски завршетак у којем је $u$ увек део творбене основе). И док суфиксни аломорф увек значи 
исто што и основни суфикс, суфиксни деривати увек значе нешто друго, што је, уосталом, и услов њихова настанка.

\section{ЛИТЕРАТУРА}

Бабић 1986: Stjepan Babić, Tvorba riječi u hrvatskom književnom jeziku, Zagreb: JAZU, Globus.

Белић 2000: Александар Белић, Савремени српскохрватски књижевни језик, Наука о грађену речи (Изабрана дела Александра Белића, т. 14), Београд: Завод за уџбенике и наставна средства.

Бошковић 2000: Радосав Бошковић, Основи упоредне граматике словенских језика, Београд: Требник.

Вондрак 1924: Wenzel Vondràk, Vergleichende slavische Grammatik I Lautlehre und Stammbildungslehre, Göttingen.

Драгићевић 2007: Рајна Драгићевић, Лексикологија српског језика, Београд: Завод за уџбенике.

Клајн 2003: Иван Клајн, Творба речи у савременом српском језику /2, Београд: Завод за уџбенике и наставна средства, Нови Сад: Матица српска.

Маројевић 1983: Радмило Маројевић, Суфикс -sk- у посесивној функиији у руском језику (у историјском развоју и данас), ЈФ XXXIX, Београд, стр. 159-178.

Маројевић 1985: Радмило Маројевић, Посесивне изведенице у староруском језику, Београд: Филолошки факултет.

Меје 1951: А. Мейе, Общеславянский язык, Москва: Издательство иностранной литературы.

Николић 2000: Мирослав Николић, Обратни речник српског језика, Београд: Матица српска, Институт за српски језик САНУ.

Скок 1973: Petar Skok, Etimologijski rječnik hrvatskoga ili srpskoga jezika III, Zagreb: Jugoslavenska akademija znanosti i umjetnosti.

Стакић 1988: Милан Стакић, Дериваџиона фонетика именица и придева y јужнословенским језииима, Београд Филолошки факултет Београдског универзитета.

Стевановић 1970: Михаило Стевановић, Савремени српскохрватски језик I, Београд: Научна књига. 
Хабургаев 1986: Г. А. Хабургаев, Старославянсий язык, Москва: „Просвещение".

Цејтлин 1986: Р. М. Цейтлин, Лексика древнеболгарских рукописей, София: Издательство болгарской академии наук.

\section{СУФФИКС -СТВО ИМЕН СУЩЕСТВИТЕЛЬНЫХ В СЕРБСКОМ ЯЗЫКЕ}

\section{Резюме}

В настоящей работе автор попытался комплексно описать и объяснить один из самых продуктивных суффиксов имен существительных в современном сербском языке - суффикс -ство. Рассматривается также: происхождение данного суффикса, значения имен существительных, которые с его помощью образовываются, мотивные слова, с которыми он находится в деривационном отношении, суффиксы-синонимы, а также алломорф -тво и дериваты суффикса -ство: -арство, -анство, -инство, -аштво (причины и способы их выделения). Работа строится на материале шеститомного словаря «Речник српскохрватскога књижевног језика» Матицы сербской.

Ключевые слова: суффикс -ство, алломорфы, дериваты, производные слова, словообразовательная структура, значения, деривационные отношения, мотивные слова, имена прилагательные, имена существительные.

М. В. Стакич 